\title{
Growth And Expansion Of Women-Owned Home-Based Business
}

John Breen, Victoria University, Australia

Stan Karanasios, Victoria University, Australia

\begin{abstract}
Home-based business (HBB) growth and expansion has been approached from the perspective of the increase in numbers of HBBs and the economic multiplier effect. However, little is known concerning the actual growth and expansion of the individual HBBs in terms of increase in turnover and sales, number of employees, increase in products and services, return on investment and market share. This is particularly true when narrowed to a specific demographic group, such as women-owned HBBs. This paper explores the growth aspirations and actual growth experiences of women-owned HBBs, as well as the factors both influencing growth and retarding growth amongst women-owned HBBs in Victoria, Australia. We found that over half of female owned HBBs have experienced growth and almost three quarters aspire for future growth. A factor analysis and subsequent correlation and one-way Anova revealed the significant factors associated with growth and retarding growth. We found that prudent business management and external factors in the form of government support and securing a major contract are important factors contributing to growth. Concerning future growth the most important factors were business management and market opportunities such as achieving exports and conducting business over the Internet. HBBs that planned to grow also placed more importance on the barriers to growth. The paper expands knowledge in the domain of women-owned HBBs and challenges the view of women-owned HBBs as less formal organisations with an indifferent attitude towards growth.
\end{abstract}

Keywords: Small business; Gender; Home based businesses; Growth; Small business management

\section{INTRODUCTION}

$\mathrm{t}$ is widely recognised that home-based businesses (HBBs) are numerically a significant proportion of total businesses and are a critical part of the economic structure in most countries (Commonwealth Government, 2004; Walker, 2003; Walker \& Webster, 2004; Walker, Weigall, \& Horgan, 2004). In
Australia, HBBs make up more than two-thirds of the small business population and while this makes HBBs the largest business cohort in the economy, more significantly, they are also the fastest growing, increasing from 58\% of all small businesses in 1997, to $68 \%$ in 2004, equivalent to over one million Australians operating in excess of 850,000 HBBs (ABS, 2004). In the United Kingdom and Canada it is estimated that almost ten percent of the working population operate a HBB (Dwelly, Maguire, \& Truscott, 2005; Federal Government of Canada, 2002), while in the USA, approximately two-thirds of all small businesses, and about half of all businesses overall, are home-based (Beale, 2004; Pratt, 2000).

HBB growth and expansion has been approached from the perspective of the increase in numbers of HBBs and the economic multiplier effect (Rowe, Haynes, \& Stafford, 1999). Nonetheless, little is known concerning the actual growth and expansion of the individual HBBs in terms of increase in sales turnover, number of employees, increase in products and services, return on investment, market share, and entry into new markets. This is particularly true when narrowed to a specific demographic group, such as women-owned HBBs. Rational economic theory would suggest that growth aspirations and realised expansion would be equivalent for men as for women, especially given the self-determinant nature of operating a HBB. However, the literature has pointed to barriers in the path to growth, differential incomes and growth aspirations between male and female owned HBBs and small 
businesses generally (Brush, 1992; N. M. Carter \& Allen, 1997; R. B. Carter, Auken, \& Harms, 1992; Catley \& Hamilton, 1998; Hughes, 2003; Kalleberg \& Leicht, 1991; Still \& Walker, 2006). This paper investigates the growth aspirations and actual growth experience of women-owned HBBs. We begin by presenting discourse on HBB and small business growth and then narrow our discussion to women-owned businesses. Next we describe the study method and present the findings of our data analysis. The paper concludes with discussion of the implications of the data analysis.

\section{CHANGING LANDSCAPE OF HBB AND SMALL BUSINESS GROWTH}

Peacock (2004) suggests that a reason for the lack of focus on growth in the small business literature is because traditional small businesses are less expansionist and are in the majority and therefore small business surveys tend to reflect the traditional rather than the entrepreneurial and growth aspects of the sector. However, the potential markets that may be reached from home are rising rapidly, particularly, for firms that export from inception (Phillips, 2002). The internationalisation of small business operations in particular is increasing, driven by globalisation, changes in domestic market conditions, owner characteristics and networks (Rutihinda, 2008). Therefore, for self-employed individuals Phillips (2002 p. 47) suggests that the home is the new model of a business incubator "in which myriad entrepreneurs begin and remain at home" and while claims that businesses in commercial premises may shift to home-based premises in order to reduce costs have not materialised, it is unequivocal that HBBs are continuing to grow in number and economic significance.

Advances in Information Communication Technologies (ICT) and their increased accessibility are another factor contributing to the growth of HBBs (Phillips, 2002; Walker, 2003). HBBs that operate predominately through the Internet are a particularly interesting sub-set of the HBBs typology concerning growth, as the Internet allows access to new markets through email, websites and extended web presences (Burgess, Sellitto, \& Karanasios, 2009). Van Gelderen, Sayers \& Keen (2008) found that Internet based HBBs generate variety because of the unique way in which they operate.

The literature also points to a number of managerial and internal imperatives for growth. Storey (1994) suggested three critical areas that contribute to growth: the owner-manager, the firm characteristics and business strategies. Similar factors have been suggested to influence or predict growth, success and innovation adoption in small businesses (Karanasios \& Burgess, 2008; Purateera, Khamanarong, Phanarata, \& Khamanarong, 2009). Other studies have shown that government support acts to stimulate growth amongst small businesses (Breen, Ali, Walker, \& Paguio, 2006). There are also a number of inhibitors to HBB growth. Generally high-growth orientated small businesses are constrained by lack of access to finance (Peacock, 2004). Beyond finance, Phillips (2002) lists state and local ordinances prohibiting business activity in the home, tax regulations that discriminate against HBBs, difficulties in accessing health insurance and discrimination by package delivery services as factors retarding the growth of HBBs.

Kirchoff (1988) placed small businesses into a widely employed typology of four sectors which explained the character of businesses on the basis of rate of innovation and rate of growth and is useful for conceptually organising businesses into growth categories. However, while most businesses may fit within the base group of the 'economic core' and few could be classed as 'glamorous' gazelles, it is unknown if changes to the HBB sector triggered by economic restructuring, the proliferation of ICTs and social factors have changed this typology of growth. In particular, it is not known if women-owned HBBs fit within this structure. Moreover, such economic centric structures and other traditional economic growth determinants such as return on investment, increased number of employees, net-income growth, increased sales, new products and services and new markets (Delmar, 2006) do not account for the personal growth measurements such as personal satisfaction and achievement, pride in the job and a flexible lifestyle, which are generally valued higher than wealth creation amongst small businesses (Walker \& Brown, 2004).

\section{GENDER, GROWTH AND HOME-BASED BUSINESS}

The cumulative literature on women-owned HBBs and small business has focused on themes such as determinants of success, industry breakdown, motivation for entering self-employment and gender differences 
(Brush, 1992; N. M. Carter \& Allen, 1997; R. B. Carter, et al., 1992; Catley \& Hamilton, 1998; Hughes, 2003; Kalleberg \& Leicht, 1991; Still \& Walker, 2006). While few authors have focused their efforts on the business growth aspirations and factors contributing to growth of women-owned HBBs and small business more generally, there are a number of themes in the literature that have expanded our broader knowledge of this area.

Much of the literature examines the relative lesser incomes and success of women-owned HBBs. Carter et al., (1992) suggested that the industry of the business, typically craft related, attributed to the lesser comparative success of female-owned small businesses. Rowe et al., (2000) found difference in the earnings of male and womenowned HBBs, in favour of men. They suggested that home-based self employment does not guarantee women an escape from the influence of gender in the workplace, particularly in terms of realised income. In a different analysis, Loscocco and Hunter (2004) examined the financial success of women-owned HBBs to women-owned business run outside of the home. Their analysis led them to conclude that home-based ownership may preferable only for women who do not have strong financial needs. This adds an extra dimension to the growth of womenowned HBBs, that is, if they are less successful financially to male owned HBBs and other women-owned businesses then do they grow and do they aspire for growth?

Cliff (1998) sheds light on this question, by positing that although male and female entrepreneurs seem equally likely to desire business growth, there appear to be important differences with respect to how they wish to expand. Her findings suggested that female entrepreneurs were more likely to establish maximum business size thresholds, beyond which they would prefer not to expand, which are lower than those set by their male counterparts. The thresholds represent the size that the entrepreneur is comfortable managing - the size that enables control of the organization, allows the owner to devote a reasonable amount of time and energy to the firm, and/or balance work and personal life. Female entrepreneurs also seemed to be more concerned than male entrepreneurs about the risks associated with fast-paced growth and tended to deliberately adopt a slow and steady rate of expansion. Therefore, for female entrepreneurs in particular, personal considerations appear to override economic considerations in the business expansion decision. Cliff's findings have important implications concerning government programs designed to increase the size and/or growth rate of female-owned businesses as they may not be relevant and suggest banks might view women as better loan risks, given their more cautious attitudes toward growth.

In terms of barriers to growth and expansion, Carter and Allen (1997) found that a lack of financial resources, more than any deliberate or socially induced choice on the part of women, appears to be the primary deterrent to growth. However, while the early literature has shed light on women-owned small businesses, the women-owned small business and HBB landscape has changed fundamentally over the last ten years, due to progress in ICT and economic and industry restructuring, social and lifestyle imperatives. Therefore, many of the notions applied to explain women-owned business growth, success and expansion in the early literature may no longer be relevant. Supporting this argument, McGregor and Tweed (2002) contend that paradigms of female business growth and expansion do not necessarily fit traditional typologies and new interpretations are needed. In their study concerning small business growth and expansion, they showed that 'networked' women, who were in the main better educated and more widely affiliated, were more expansionist than both other female small business owners and men, contradicting the literature that suggests women were less growth-orientated and desired solely to satisfy intrinsic needs from their businesses. Providing a different perspective, Powell and Eddleston (2008) suggested female business owners placed less value on achieving business success than their male counterparts. Also, female business owners' satisfaction with business success was less related to fluctuations in business performance and sales than that of male business owners, suggesting that success for women is not based on traditional business performance measures. In an earlier paper Breen (2008) proposed that there are several areas where women could be considered as more serious and methodological in their business approach and better at planning and preparing for their business venture. We found women are more likely to seek professional advice and use formal networks and government support services to help with their business development, supporting some of the literature that suggested that women use support services and those that are networked are more expansionist (McGregor \& Tweed, 2002; Still \& Walker, 2006). We also found that women-owned HBBs aspired for growth more than males, however the details of their growth aspirations and factors facilitating and retarding growth were not explored. 
It is unequivocal from the literature that a more detailed inquiry of female-owned businesses is necessary in order to understand their growth aspirations and factors contributing to and retarding growth. This is important against the backdrop of the proliferation of women-owned HBBs and lack of understanding of how these businesses are managed. Along these lines, scholars have identified a need for more research on how women act as owners and managers of small businesses and their growth aspirations (Catley \& Hamilton, 1998; Cliff, 1998; McGregor \& Tweed, 2002). Government agencies have also called for inquiry into the structure and needs of this sector, in order to improve assistance to residents running a HBB (Outer Suburban/Interface Services and Development Committee., 2008). By undertaking research on this sector, government, industry associations and business development agencies will be better informed to support the precise needs and aspirations of women-owned HBB and help mitigate growth obstacles.

In order to address the paucity of research focusing on women-owned HBBs and growth, we analyse a data set of women-owned HBBs to explore growth motivations, aspirations, factors facilitating growth and factors retarding growth. We also test hypotheses formed from the literature review based on the underlying notions that the Internet and the internationalisation effect are a facilitator of growth and that women-owned HBBs are more methodological planners and well networked, that is, their prudent business management plays a role in growth.

\section{THE STUDY}

In order to capture data on the characteristics of HBBs a questionnaire was administered via mail and email/online through a database of HBBs. As many as 20 Local Government Authorities and two support agencies across Metropolitan and Regional Victoria provided valuable assistance in the widespread online and mail distribution of the survey to their constituent HBBs. Victoria is Australia's second most populous state, with 5.4 million inhabitants recorded in 2009 (ABS, 2009). To obtain a state-wide perspective, geographically dispersed councils were surveyed, limiting any bias from regional effects. The questionnaire design followed the process of a piloting and refinement phase in order to test its clarity, usability and responses. Questions focused on the dimensions of the business and the factors that have supported or restricted growth and included non-comparative scale (Likert-type scale), pairwise comparison, and open-ended questions.

Table 1: Summary of Women-Owned HBB Characteristics

\begin{tabular}{|c|c|c|c|}
\hline \multicolumn{2}{|l|}{ Location } & \multicolumn{2}{|c|}{ Characteristics of the Business Operations } \\
\hline Metropolitan location & $53.1 \%$ & Those who sub-contract & $16.7 \%$ \\
\hline Regional/rural location & $46.9 \%$ & Those who operate as a franchise & $3.8 \%$ \\
\hline \multicolumn{2}{|l|}{$\begin{array}{ll}\text { Industry Sectors } \\
\end{array}$} & HBB is primary source of income & $61.5 \%$ \\
\hline Manufacturing & $9.6 \%$ & Spouse/partner involved in HBB & $29.8 \%$ \\
\hline Construction & $3.3 \%$ & No family member involved & $56.6 \%$ \\
\hline Wholesale and Retail & $6.8 \%$ & Interstate customers & $57.5 \%$ \\
\hline Accommodation and Food Services & $8.3 \%$ & Overseas customers & $32.1 \%$ \\
\hline Technical Services & $8.6 \%$ & Prepare a written business plan & $36.3 \%$ \\
\hline Management, Legal and Accounting Services & $19.2 \%$ & Average working hours per week & 33.89 \\
\hline Administration Services & $8.6 \%$ & Average years in operation & 7.45 \\
\hline Education and Health Services & $14.1 \%$ & Average number of full-time employees & 1.23 \\
\hline Arts, Recreational and Personal Services & $15.4 \%$ & Average number of part-time employees & 1.50 \\
\hline Miscellaneous & $6.1 \%$ & \multicolumn{2}{|l|}{$\begin{array}{ll} & \text { Education } \\
\end{array}$} \\
\hline \multicolumn{2}{|l|}{ Age } & Secondary School & $23.7 \%$ \\
\hline Under 30 & $5.8 \%$ & Certificate/Diploma & $35.5 \%$ \\
\hline $30-39$ years & $24.3 \%$ & University degree & $40.8 \%$ \\
\hline $40-49$ years & $35.0 \%$ & Other & \\
\hline $50-59$ years & $26.8 \%$ & Membership of a business association & $52.1 \%$ \\
\hline 60 plus & $8.3 \%$ & Living with dependents & $47.6 \%$ \\
\hline
\end{tabular}

Of the 7484 questionnaires distributed, 978 (13\%) usable responses were returned. A total of $41.5 \%$ of the responses came from female HBB operators, leaving us with 406 valid responses from women-owned HBBs. There 
were a number of significant differences between female and male businesses owners in terms of age of HBB, motivations for entering self-employment, age profile of the operators, reasons for operating from home and planning approaches (Breen, et al., 2008). Table 1 provides a summary of the characteristics of the women-owned HBBs. Data was analysed using SPSS.

\section{DATA ANALYSIS}

The structure of the analysis is as follows. First, we examined initial and future growth aspirations and whether HBBs achieved their initial growth goals. This allowed us to determine if women-owned HBBs were matching their initial business growth aspirations. Second, we examined future growth aspirations and the desire to move to commercial premises. This provided a different perspective on growth aspirations by examining HBBs that desired expansion beyond being a HBB. Third, we analysed the factors that contributed to and retarded growth based on experienced growth and future growth aspirations. In order to undertake the three levels of analysis described we performed cross tabulations and independent sample t-tests to provide some descriptive analysis and then performed a factor analysis and subsequent correlation analysis and one-way ANOVA in order to examine growth in more detail.

\section{Initial and future growth aspirations}

Women HBB owners were asked to indicate their initial and future growth aspirations. These are summarised as percentages in Table 2, and indicate that more than half of women-owned HBBs initially aspired to grow from inception and more than two thirds planned to grow in the future. Furthermore, $71.3 \%$ of women indicated that they had matched their initial growth expectations, and $60.5 \%$ of women that wanted to grow moderately or significantly achieved their target.

Table 2: Initial and Future Growth Aspirations

\begin{tabular}{|l|l|c|}
\hline \multirow{4}{*}{ Initial growth aspirations } & & Female \\
\hline \multirow{4}{*}{ Future growth aspirations } & That would stay small and manageable & $33.9 \%$ \\
\cline { 2 - 3 } & That would grow moderately & $49.4 \%$ \\
\cline { 2 - 3 } & That would grow significantly & $15.5 \%$ \\
\hline & To become smaller & $1.7 \%$ \\
\cline { 2 - 3 } & To stay the same & $17.2 \%$ \\
\cline { 2 - 3 } & To grow moderately & $56.1 \%$ \\
\cline { 2 - 3 } & To grow significantly & $24.4 \%$ \\
\hline
\end{tabular}

\section{FUTURE GROWTH AND MOVE TO COMMERCIAL PREMISES}

A total of 17.6 percent of businesses wanted to move out of their home premises into commercial premises, and 60 percent of these businesses want to grow significantly, and $37.1 \%$ moderately. A cross tabulation analysis of future aspirations for growth and the aspirations to move to commercial premises revealed significant association $\chi 2(3, N=395)=60.838, \mathrm{p}<.05$, indicating planning and forethought concerning the trajectory of the business.

\section{Experienced growth and factors facilitating and retarding growth}

We asked respondents to indicate whether in recent times they had 1) employed more staff 2) significantly increased sales turnover 3) increased the number of products/services, and 4) invested significantly in equipment or technology. These measurements are approximately consistent with the growth dimensions articulated in the literature and were used to define growth cohorts within the sample. Figure 1 illustrates the proportion of HBBs that indicated growth based on none, or one or more growth indicators. 


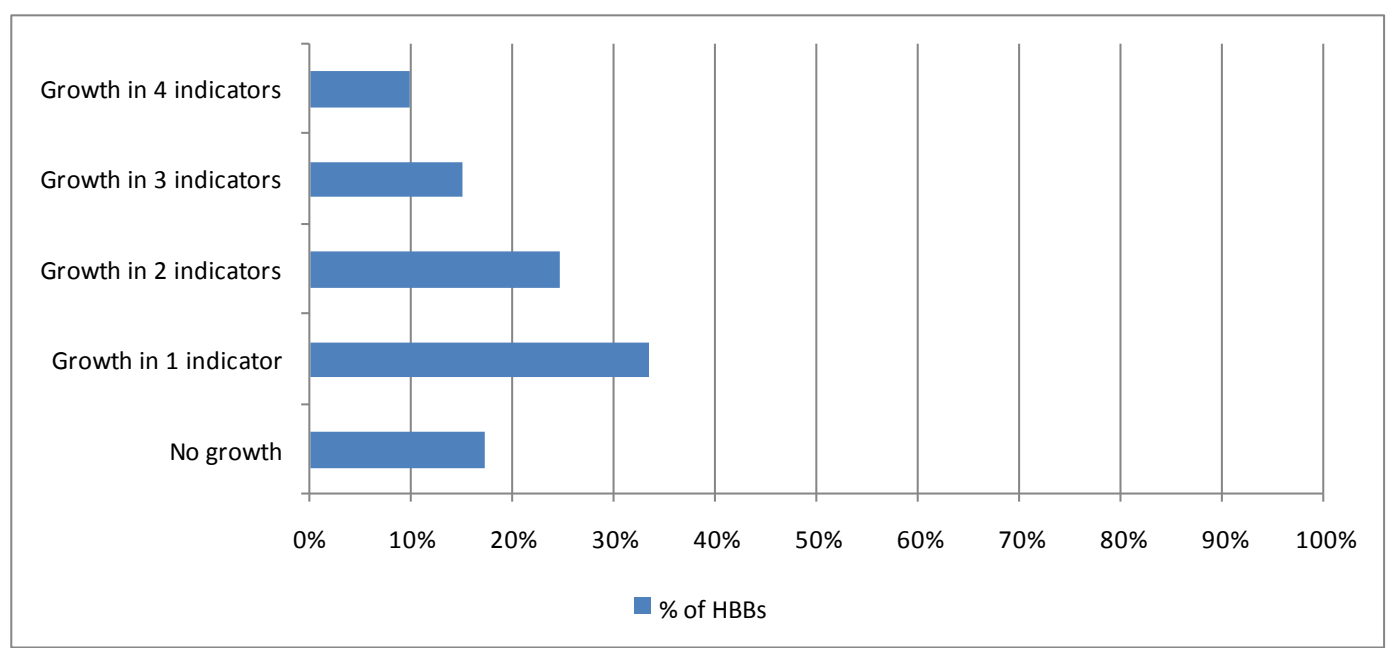

Figure 1: Growth Indicators

A correlation was undertaken for the five cohorts of growth and some specific HBB characteristics. It was hypothesised that a positive relationship would exist between the five growth groups and the number of hours worked per week. Results of the correlation indicate that higher number of hours worked per week are associated with greater growth $(\mathrm{r}=.386, \mathrm{p}<.05)$. We also examined the correlation between growth and age of the business operator and years in operation. We found there was no correlation between the five growth cohorts and years in operation or age of operator.

For non-continuous variables we undertook cross tabulation analysis in order to determine statistical differences between the five growth groups. The results revealed significant difference between the five cohorts concerning whether the business was the primary source of income $\chi^{2}(4, N=360)=18.207, \mathrm{p}<.05$, and whether it had overseas customers $\chi^{2}(4, N=335)=11.080, \mathrm{p}<.05$ or interstate customers $\chi 2(4, N=334)=9.750, \mathrm{p}<.05$. However, there was no significant statistical difference between the five cohorts concerning whether it was a franchise or subcontractor, by location or industry category.

\section{FACTORS THAT SUPPORT AND RESTRICT GROWTH}

To identify the underlying constructs that women-owned HBBs found important in achieving growth we conducted a factor analysis on the variables important for the growth of their business. After analysing the component matrix it was established that factor analysis was appropriate as the KMO measure of sampling adequacy was 0.82 . We used principle component analysis to extract the factors and three factors emerged with Eigenvalues greater than one, as depicted in Table 3. These three factors explained 51.5\% of the total variance.

Table 3: Amount of Variance Explained by Each Component

\begin{tabular}{|c|c|c|c|c|}
\hline \multirow{2}{*}{ Component } & $\boldsymbol{\lambda}$ & \% of Variance before rotation & \% of Variance explained after rotation & Cumulative \% \\
\hline & 3.751 & 31.260 & 24.000 & 31.260 \\
\hline 1 & 1.400 & 11.670 & & 42.930 \\
\hline 2 & 1.029 & 8.577 & & 51.506 \\
\hline 3 & .952 & & & \\
\hline 5 & .832 & & & \\
\hline 6 & .745 & & & \\
\hline 7 & .708 & & & \\
\hline 8 & .661 & & & \\
\hline 9 & .572 & & & \\
\hline 10 & .513 & & & \\
\hline 11 & .451 & & & \\
\hline 12 & .384 & & & \\
\hline
\end{tabular}


The three extracted components were then rotated using a varimax rotation, which converged in 5 iterations. The results are shown in Table 4 . Variables that loaded above 0.4 on more than one factor were removed. From the factor loadings we interpret the factors to be Prudent Management, Pursuing Distribution and Exploiting Customers and Support.

Table 4: Growth Factors

\begin{tabular}{|l|c|c|c|}
\hline \multicolumn{2}{|c|}{} & \multicolumn{2}{c|}{ Component } \\
\cline { 2 - 4 } & $\begin{array}{c}\text { Prudent } \\
\text { Management } \\
\text { Distribuing }\end{array}$ & $\begin{array}{c}\text { Exploiting Customers } \\
\text { and Support }\end{array}$ \\
\hline Carefully prepared business plan & 0.739 & \\
\hline Using professional business advice & 0.735 & \\
\hline Undertaking training & 0.635 & \\
\hline Formal networking & 0.599 & & \\
\hline Superior marketing or selling skills & 0.535 & & \\
\hline New market opportunity & 0.501 & & \\
\hline Access to finance / capital & 0.488 & & \\
\hline Conducting your business over the Internet & & & \\
\hline Achieving export sales & & & \\
\hline Securing a major contract / customer & & 0.735 & \\
\hline Government support (e.g. information, funding) & & & 0.792 \\
\hline
\end{tabular}

Using the same procedure we analysed the underlying factors important in restricting the growth of the business, the results are shown in Tables 5 and 6. Only one factor emerged with an Eigenvalue greater than one, this factor explained $35.6 \%$ of variance.

Table 5: Amount of Variance Explained by Each Factor

\begin{tabular}{|c|c|c|c|}
\hline \multirow{2}{*}{ Component } & \multicolumn{3}{|c|}{ Eigenvalues } \\
\cline { 2 - 4 } & $\boldsymbol{\lambda}$ & \% of Variance & Cumulative \% \\
\hline 1 & 2.848 & 35.6 & \\
\hline 2 & 0.952 & & \\
\hline 3 & 0.871 & & \\
\hline 4 & 0.845 & & \\
\hline 5 & 0.753 & & \\
\hline 6 & 0.692 & & \\
\hline 7 & 0.574 & & \\
\hline 8 & 0.465 & & \\
\hline
\end{tabular}

As only one factor emerged from the extraction no rotation is necessary. This underlying factor is labelled general restrictions. The loadings of each component are shown in Table 6.

Table 6: Growth Restrictions

\begin{tabular}{|l|c|}
\hline \multirow{2}{*}{} & Component \\
\cline { 2 - 2 } & General Restrictions \\
\hline Lack of business support network for HBBs & 0.739 \\
\hline Customers have a negative perception of HBBs & 0.692 \\
\hline Lack of business skills & 0.672 \\
\hline My dislike of risk & 0.579 \\
\hline Skills shortage in industry & 0.537 \\
\hline Lack of IT infrastructure in area & 0.518 \\
\hline Family commitments & 0.502 \\
\hline Lack of finance / capital & 0.477 \\
\hline
\end{tabular}


Having identified the underlying factors that contribute to or restrict growth for women-owned HBBs, we then tested whether groups based on their recent growth or their future growth intentions differed in respect to the importance it placed on each factor created by the factors analysis (Prudent Management, Pursuing Distribution, Exploiting Customers and Support, General Restrictions to Growth).

\section{RECENT GROWTH: FACTORS IMPORTANT TO GROWTH AND RESTRICTIONS TO GROWTH}

We hypothesized there is a relationship between the importance placed on the underlying factors for growth and the amount of recent growth, as measured by the total number of positive growth indicators. Specifically, we hypothesized there would be a relationship between the number of positive growth indicators and the importance of factors that contribute to growth and a relationship between the number of positive indicators and the importance placed on general restrictions on growth. Using the patterns of relationships amongst the variables revealed in the factor analysis we undertook a correlation in order answer the following:

H1a: There is a positive relationship between the number of growth indicators and the importance placed on factors that contribute to growth.

H1b: There is a negative relationship between the number of growth indicators and the importance placed on factors restricting growth.

As can be seen from the Table 7 there is a significant positive relationship between the number of positive growth indicators reported and the importance placed on Prudent Business Management for growth and the importance placed on Exploiting Customers and Support to growth. This means that participants who reported a higher number of positive growth indicators were more likely to place a higher importance on Prudent Business Management and Exploiting Customers and Support. It should also be noted that there is a non-significant positive relationship between the importance of Pursuing Distribution and the number of positive growth indicators. Table 7 also reveals that there is no significant relationship between growth indicators and general restrictions to growth. We therefore accept H1a and reject H1b.

Table 7: Correlations Between Growth Indicators and Factors

\begin{tabular}{|l|l|c|c|c|c|}
\hline \multicolumn{2}{|c|}{} & $\begin{array}{c}\text { Importance of } \\
\text { Prudent Business } \\
\text { Management }\end{array}$ & $\begin{array}{c}\text { Importance of } \\
\text { Pursuing } \\
\text { Distribution }\end{array}$ & $\begin{array}{c}\text { Importance of } \\
\text { Exploiting customers } \\
\text { and support }\end{array}$ & $\begin{array}{c}\text { General } \\
\text { restrictions }\end{array}$ \\
\hline \multirow{2}{*}{$\begin{array}{l}\text { No of Positive } \\
\text { Growth } \\
\text { indicators }\end{array}$} & Pearson Correlation & .133 & .105 & .133 & .063 \\
\cline { 2 - 6 } & Sig. (2-tailed) & .013 & .052 & .014 & .244 \\
\cline { 2 - 7 } & $\mathbf{N}$ & 345 & 345 & 345 & 342 \\
\hline
\end{tabular}

\section{FUTURE GROWTH ASPIRATIONS: FACTORS IMPORTANT TO GROWTH AND RESTRICTIONS TO GROWTH}

We hypothesized that future growth intentions will affect the importance participants place on the underlying growth factors. Specifically those groups who plan to grow will place more importance on growth factors, both positive and negative, than those groups who plan to become smaller or stay the same. Therefore the hypothesis tested here is:

H2: There is significant variation concerning factors contributing to growth and barriers to growth based on future growth intentions.

Using the same factors, a one-way analysis of variance (ANOVA) was calculated on the test for differences in importance participants place on the underlying factors that contribute to and restrict growth across the four groups based on their preferences for future growth (become smaller, stay the same, grow moderately, grow significantly). A one-way ANOVA was used in this instance because there are more than two groups to compare means on a variable. Tables 9-12 show the comparisons for experienced growth and future growth intentions and the factors contributing to or restricting growth. 
Table 8: ANOVA

\begin{tabular}{|c|c|c|c|c|c|c|}
\hline & & Sum of Squares & df & Mean Square & $\mathbf{F}$ & Sig. \\
\hline \multirow{3}{*}{$\begin{array}{l}\text { Importance of Prudent Business } \\
\text { Management to growth }\end{array}$} & Between Groups & 22.796 & 3 & 7.599 & 8.127 & .000 \\
\hline & Within Groups & 344.055 & 368 & .935 & & \\
\hline & Total & 366.851 & 371 & & & \\
\hline \multirow{3}{*}{$\begin{array}{l}\text { Importance of Pursuing } \\
\text { Distribution }\end{array}$} & Between Groups & 35.527 & 3 & 11.842 & 12.954 & .000 \\
\hline & Within Groups & 336.432 & 368 & .914 & & \\
\hline & Total & 371.959 & 371 & & & \\
\hline \multirow{3}{*}{$\begin{array}{l}\text { Importance of Exploiting } \\
\text { Customers and Support to } \\
\text { growth }\end{array}$} & Between Groups & 2.106 & 3 & .702 & .700 & .553 \\
\hline & Within Groups & 369.084 & 368 & 1.003 & & \\
\hline & Total & 371.190 & 371 & & & \\
\hline \multirow{3}{*}{$\begin{array}{l}\text { Importance of general } \\
\text { restrictions to growth }\end{array}$} & Between Groups & 8.469 & 3 & 2.823 & 2.863 & .037 \\
\hline & Within Groups & 358.960 & 364 & .986 & & \\
\hline & Total & 367.429 & 367 & & & \\
\hline
\end{tabular}

As can be seen from Table 8 the groups significantly varied concerning the importance placed on Prudent Business Management, $\mathrm{F}(3,368)=8.1, p<0.001$. Further analysis of this factor using Tukey's post-hoc comparisons (Table 9) for the four groups indicates that the grow significantly group placed significantly more importance on Prudent Business Management than the get smaller, stay the same and grow moderately group. Comparisons between the other three groups were not significantly different.

Table 9: Importance of Prudent Business Management and Future Growth Aspirations

\begin{tabular}{|c|c|c|c|c|}
\hline \\
\hline Dependent Variable & $\begin{array}{c}\text { (I) Future aspiration for } \\
\text { business }\end{array}$ & $\begin{array}{c}\text { (J) Future aspiration for } \\
\text { business }\end{array}$ & Mean Difference (I-J) & Sig. \\
\hline \multirow{12}{*}{$\begin{array}{l}\text { Importance of Prudent } \\
\text { Business Management }\end{array}$} & \multirow[t]{3}{*}{ Become smaller } & Stay the same & -.4740 & .661 \\
\hline & & Grow moderately & -.7454 & .246 \\
\hline & & Grow significantly & -1.1501 & .025 \\
\hline & \multirow[t]{3}{*}{ Stay the same } & Become smaller & .4740 & .661 \\
\hline & & Grow moderately & -.2714 & .213 \\
\hline & & Grow significantly & -.6760 & .000 \\
\hline & \multirow[t]{3}{*}{ Grow moderately } & Become smaller & .7454 & .246 \\
\hline & & Stay the same & .2714 & .213 \\
\hline & & Grow significantly & -.4047 & .004 \\
\hline & \multirow[t]{3}{*}{ Grow significantly } & Become smaller & 1.1501 & .025 \\
\hline & & Stay the same & .6760 & .000 \\
\hline & & Grow moderately & .4047 & .004 \\
\hline
\end{tabular}

The groups also significantly varied in the importance placed on Pursuing Distribution for growth, F(3,371) $=11.8, p<0.001$. Tukey's post-hoc comparisons (Table 10) for the four groups indicates that the grow significantly group placed significantly more importance on Pursuing Distribution as a factor that contributed to growth than the grow moderately and stay the same groups. The grow moderately group placed significantly more importance on Pursuing Distribution as a factor than the stay the same group. Interestingly the get smaller group did not significantly vary from any other group concerning the importance placed in Pursuing Distribution as a factor. 
Table 10: Importance of Pursuing Distribution and Future Growth Aspirations

\begin{tabular}{|c|c|c|c|c|}
\hline Dependent Variable & $\begin{array}{c}\text { (I) Future aspiration for } \\
\text { business }\end{array}$ & $\begin{array}{c}\text { (J) Future aspiration for } \\
\text { business }\end{array}$ & Mean Difference (I-J) & Sig. \\
\hline \multirow{12}{*}{$\begin{array}{l}\text { Importance of Pursuing } \\
\text { Distribution }\end{array}$} & \multirow{3}{*}{ Become smaller } & Become smaller & .4699 & .659 \\
\hline & & Grow moderately & -.0759 & .997 \\
\hline & & Grow significantly & -.4983 & .603 \\
\hline & \multirow[t]{3}{*}{ Stay the same } & Become smaller & -.4699 & .659 \\
\hline & & Grow moderately & -.5458 & .001 \\
\hline & & Grow significantly & -.9681 & .000 \\
\hline & \multirow[t]{3}{*}{ Grow moderately } & Become smaller & .0759 & .997 \\
\hline & & Stay the same & .5458 & .001 \\
\hline & & Grow significantly & -.4223 & .002 \\
\hline & \multirow[t]{3}{*}{ Grow significantly } & Become smaller & .4983 & .603 \\
\hline & & Stay the same & .9681 & .000 \\
\hline & & Grow moderately & .4223 & .002 \\
\hline
\end{tabular}

There was no significant variation between the groups on the importance placed on Exploiting Customers and Support as a contributor to growth (Table 11).

Table 11: Importance of Exploiting Customers and Support and Future Growth Aspirations

\begin{tabular}{|c|c|c|c|c|}
\hline Dependent Variable & $\begin{array}{c}\text { (I) Future aspiration for } \\
\text { business }\end{array}$ & $\begin{array}{c}\text { (J) Future aspiration for } \\
\text { business }\end{array}$ & Mean Difference (I-J) & Sig. \\
\hline \multirow{12}{*}{$\begin{array}{l}\text { Importance of Exploiting } \\
\text { Customers and Support }\end{array}$} & \multirow{3}{*}{ Become smaller } & Stay the same & -.1215 & .992 \\
\hline & & Grow moderately & -.3090 & .879 \\
\hline & & Grow significantly & -.2719 & .917 \\
\hline & \multirow[t]{3}{*}{ Stay the same } & Become smaller & .1215 & .992 \\
\hline & & Grow moderately & -.1876 & .567 \\
\hline & & Grow significantly & -.1505 & .793 \\
\hline & \multirow[t]{3}{*}{ Grow moderately } & Become smaller & .3090 & .879 \\
\hline & & Stay the same & .1876 & .567 \\
\hline & & Grow significantly & .0371 & .991 \\
\hline & \multirow[t]{3}{*}{ Grow significantly } & Become smaller & .2719 & .917 \\
\hline & & Stay the same & .1505 & .793 \\
\hline & & Grow moderately & -.0371 & .991 \\
\hline
\end{tabular}

The groups did significantly vary on the importance of General Restrictions to growth on their business, $\mathrm{F}(3,364)=2.9, p=0.037$ ). Tukey's post-hoc comparisons (Table 12) indicate that no group significantly varies from the other; however those with growth intentions have higher mean scores than those who plan to get smaller or stay the same.

Table 12: Importance of Factors and Future Growth Aspirations

\begin{tabular}{|c|c|c|c|c|}
\hline Dependent Variable & $\begin{array}{c}\text { (I) Future aspiration for } \\
\text { business }\end{array}$ & $\begin{array}{c}\text { (J) Future aspiration for } \\
\text { business }\end{array}$ & Mean Difference (I-J) & Sig. \\
\hline \multirow{12}{*}{$\begin{array}{l}\text { Factor for restrictions to } \\
\text { growth }\end{array}$} & \multirow[t]{3}{*}{ Become smaller } & Stay the same & -.4229 & .709 \\
\hline & & Grow moderately & -.7063 & .251 \\
\hline & & Grow significantly & -.7890 & .181 \\
\hline & \multirow[t]{3}{*}{ Stay the same } & Become smaller & .4229 & .709 \\
\hline & & Grow moderately & -.2834 & .200 \\
\hline & & Grow significantly & -.3661 & .116 \\
\hline & \multirow[t]{3}{*}{ Grow moderately } & Become smaller & .7063 & .251 \\
\hline & & Stay the same & .2834 & .200 \\
\hline & & Grow significantly & -.0827 & .912 \\
\hline & \multirow[t]{3}{*}{ Grow significantly } & Become smaller & .7890 & .181 \\
\hline & & Stay the same & .3661 & .116 \\
\hline & & Grow moderately & .0827 & .912 \\
\hline
\end{tabular}




\section{DISCUSSION OF THE DATA ANALYSIS AND IMPLICATIONS}

The analysis provided an interesting basis for discussion concerning not only the relationship between growth experience and future growth aspirations but also the pertinent factors contributing to and retarding growth. The analysis showed that over half of women-owned HBBs wanted to grow moderately and one quarter aspired to grow significantly. This suggests that growth is an important component of the women-owned HBB mindset. And, while Phillips (2002) suggested that there are a myriad of businesses that begin and stay at home, our analysis suggests that slightly more than one in six (17.6\%) of the women-owned HBBs aimed to move to commercial premises. Analysis also revealed significant association between future growth aspirations and desire to move to commercial premises, indicating planning and forethought concerning the future of the business. Importantly, this demonstrates a development focus set by women-owned HBBs and contradicts the notion that women-owned HBBs are not growth orientated or not serious in their business intentions. We also found a relationship between experienced growth and the number of hours worked per week, and significant association concerning whether the business was the primary source of income and overseas and interstate customers, suggesting these factors are important concerning business growth.

Kirchoff's (1988) typology of small businesses provides a useful framework for considering the HBBs surveyed in this study. The 'ambitious gazelles' characterised as high growth and high innovation businesses can be aligned with those HBBs that reported growth on all four growth indicators. In this study they accounted for $9.8 \%$ of the HBB sample which is slightly above the numbers of gazelles or high growth businesses identified in other studies (Peacock, 2004; Storey, 1994; Yellow Pages., 1995).

The factor analysis itself provided instructive results. By reducing a large number of variables to a smaller set of underlying factors that summarise the structure of the set of variables we are able to learn which variables are using the same constructs. Examination of the items indicates that they represent conceptually distinct sets of characteristics, which we labelled as Prudent Business Management, Exploiting Customers and Support, Pursuing Distribution and Restrictions to Growth.

We found business management factors (Prudent Management) are related to experienced growth. That is, women-owned $\mathrm{HBBs}$ with managerial qualities such as carefully developed business plans, that make use of professional advice and formal networks and have access to capital and marketing skills are more likely to have experienced growth. This contention is supported by the literature (Storey, 1994). Similarly there was a correlation between the importance placed on Exploiting Customers and Support - government support and securing a major contract - and growth. It also merits mentioning that there was a non-significant positive relationship between Pursuing Distribution and growth. That is, women-owned HBBs that place importance on conducting business over the Internet and export markets are more likely to have experienced growth. We expected a stronger relationship concerning this factor and growth given the literature that suggests that the Internet is a conduit for growth and more broadly the internationalisation of small business. At the same time, others have found that Internet based HBBs were not necessarily inclined to grow (Gelderen, et al., 2008). The analysis also revealed that there was no significant relationship between growth indicators and general restrictions to growth.

Concerning future growth it was found that the groups (become smaller, stay the same, grow moderately, grow significantly) significantly varied in the importance placed on Prudent Management, and Pursuing Distribution for growth, and General Restrictions to growth of their business, there was however no significant variation between the groups on the importance placed on Exploiting Customers and Support. In other words, for women-owned HBBs with growth intentions, managerial and market access factors are important to growth and women-owned HBBs that planned to grow placed more importance on restrictions to growth. This suggests that HBBs that are not interested in growth consider factors that are restricting their growth less important. Ramaseshan \& Soutar (1996) discovered a similar phenomenon concerning export, that is, small firms that did not perceive barriers to export were those that had little propensity to export.

The one-way Anova and subsequent Tukey's post-hoc comparison indicate a clear relationship between the desire to grow significantly and Prudent Management and Pursuing Distribution, and supports the contention that HBBs that want to grow significantly place more emphasis on planning, networking, using professional advice, obtaining access to capital, accessing export markets and using the Internet to conduct business. 


\section{CONCLUSION}

This paper investigated the growth of women-owned HBBs and future growth aspirations and indicated a number of factors that contribute to and retard growth. The findings presented in this paper are based on a large sample of HBBs located in Victoria, Australia. The results of this study are important for those interested in HBBs, particular women-owned HBBs, as it suggests that women-owned HBBs aspire for growth with a significant portion desiring a move beyond operating a HBB and moving into commercial premises. This challenges conventional views of women-owned HBBs as stagnant and not growth orientated. Importantly, HBBs that wanted to grow in the future placed importance on management factors and accessing markets, suggesting that while there is an aspiration to grow there is the realization of the planning necessary. More research is required in this sector in order for government, industry associations and business development agencies to better support the precise needs and aspirations of women-owned HBBs and help mitigate the obstacles to growth.

\section{AUTHOR INFORMATION}

Professor John Breen is the Director of the Centre for Tourism and Services Research at Victoria University, Australia and has been involved in research into the small business sector for twenty years. He has served on industry committees and provided advice to governments on small business policy. His research interests include home-based businesses, small business contributions to the community and entrepreneurship education.

Dr Stan Karanasios is a Research Fellow at the Centre for Tourism and Services Research at Victoria University, Australia and a Visiting Research Fellow at the University of Leeds in the United Kingdom. His research interests include small business and the adoption and use of Information Communication Technologies.

\section{REFERENCES}

1. ABS (2004). Characteristics of Small Business, Australia Retrieved January 27, 2010, from http://www.abs.gov.au/AUSSTATS/abs@.nsf/allprimarymainfeatures/54B9D7D5493E67B5CA25749C00 $11424 \mathrm{E}$ ?opendocument

2. $\quad$ ABS (2009). Australian Demographic Statistics, June 2009. 3101.0 Retrieved March 1, 2010, from http://www.abs.gov.au/ausstats/abs@.nsf/mf/3101.0

3. Beale, H. (2004). Home-based business and government regulation. Report to the Small Business Administration. Washington, D.C.: Office of Advocacy, US Government.

4. Breen, J., Ali, S., Walker, E., \& Paguio, R. (2006). Local Government Assistance for Home Based Businesses: is it worth it? Paper presented at the 51st ICSB World Conference.

5. Breen, J., Paguio, R., \& Bergin-Seers, S. (2008, 15th -17th September). Women in home based businesses: Are they serious? Paper presented at the Small Enterprise Association of Australia \& New Zealand (SEAANZ) Conference, Sydney, Australia.

6. Brush, C. G. (1992). Research on Women Business Owners; Past Trends, a New Perspective and Future Directions. Entrepreneurship Theory and Practice, Summer, 1-30.

7. Burgess, S., Sellitto, C., \& Karanasios, S. (2009). Effective Web Presence Solutions for Small Businesses: Strategies and Successful Implementation: IGI Global.

8. Carter, N. M., \& Allen, K. R. (1997). Size determinants of women-owned businesses: choice or barriers to resources? Entrepreneurship \& Regional Development, 9(3), 211-220.

9. Carter, R. B., Auken, H. E. V., \& Harms, M. B. (1992). Home-based businesses in the rural United States economy: differences in gender and financing. Entrepreneurship \& Regional Development, 4(3), 245-257.

10. Catley, S., \& Hamilton, R. T. (1998). Small business development and gender of owner. The Journal of Management Development, 17(1), 70-82.

11. Cliff, J. E. (1998). Does one sixe fit all? Exploring the relationship between attitudes towards growth, gender, and business size. Journal of Business Venturing, 13, 523-542.

12. Commonwealth Government (2004). Home-based business: Local opportunities. Canberra.

13. Delmar, F. (2006). Measuring growth: methodological considerations and empirical results. In P. Davidsson, F. Delmar \& J. Wiklund (Eds.), Entrepreneurship and the Growth of Firms (1 ed., pp. 62-84). Cheltenham, UK: Edward Elgar Publishing Limited.

14. Dwelly, T., Maguire, K., \& Truscott, F. (2005). Under the radar: Tracking and supporting rural home based business. A report for the Commission for Rural Communities from Live Work Network. London. 
15. Federal Government of Canada (2002). Starting a home-based business: A manuel for success, Solutions for small business: Western Economic Diversification and B.C. Ministry of Competition, Science and Enterprise.

16. Gelderen, M. v., Sayers, J., \& Keen, C. (2008). Home-based internet businesses as drivers of variety. Journal of Small Business and Enterprise Development, 15(1), 162-177.

17. Hughes, K. D. (2003). Pushed or Pulled? Women's Entry into Self-Employment and Small Business Ownership. Gender, Work and Organization, 10(4), 433-454.

18. Kalleberg, A. L., \& Leicht, K. T. (1991). Gender and Organizational Performance: Determinants of Small Business Survival and Success. The Academy of Management Journal,, 34(1), 136-161.

19. Karanasios, S., \& Burgess, S. (2008). Tourism and Internet adoption: a developing world perspective. International Journal of Tourism Research, 10(2), 169-182.

20. Kirchoff, B. A. (1988). A multi-sector approach to small busines policy development. In R. J. Judd (Ed.), Small Business in a Regluated Economy: Issues and Policy Implications. Ney York: Quorom Books.

21. Loscocco, K., \& Smith-Hunter, A. (2004). Women home-based business owners: insights from comparative analyses. Women in Management Review, 19(3), 164-173.

22. McGregor, J., \& Tweed, D. (2002). Profiling a New Generation of Female Small Business Owners in New Zealand: Networking, Mentoring and Growth. Gender, Work \& Organization, 9(4), 420-438.

23. Outer Suburban/Interface Services and Development Committee. (2008). Local Economic Development in Outer Suburban Melbourne. Melbourne: Outer Suburban/Interface Services and Development Committee

24. Peacock, R. W. (2004). Understanding small business: practice, theory and research: Scarman Publishing.

25. Phillips, B. D. (2002). Home-based firms, e-commerce and high-technology small firms: Are they related? Economic Development Quarterly, 16(1), 39-48.

26. Powell, G. N., \& Eddleston, K. A. (2008). The paradox of the contented female business owner. Journal of Vocational Behavior, 73, 24-36.

27. Pratt, J. (2000). Homebased business: The hidden economy (No. 194). Dallas, Texas: United States Small Business Administration.

28. Purateera, T., Khamanarong, S., Phanarata, A., \& Khamanarong, K. (2009). Influence Factors Affecting Management Of Small Enterprises In Northeast Thailand International Business \& Economics Research Journal 8(2), 41-46.

29. R.Rowe, B., Stafford, K., Walker, R., Haynes, G. W., \& Arbuthnot, J. (2000). Unexpected outcomes: The economics of genderdized home-based businesses. In S. L. Charles B. Hennon, Rosemary Adams Walker (Ed.), Gender and home-based employment (pp. 45-78). Westport CT, USA: Greenwood Publishing Group Inc.

30. Ramaseshan, B., \& Soutar, G. N. (1996). Combined effects of incentives and barriers on firms' export decisions. International Business Review, 5(1), 53-65.

31. Rowe, B. R., Haynes, G. W., \& Stafford, K. (1999). The Contribution of Home-Based Business Income to Rural and Urban Economies Economic Development Quarterly, 13(1), 66-77.

32. Rutihinda, C. (2008). Factors Influencing The Internationalization Of Small And Medium Size Enterprises International Business \& Economics Research Journal 7(12), 46-54.

33. Still, L. V., \& Walker, E. A. (2006). The self-employed woman owner and her business; An Australian profile. Women in Management Review.

34. Storey, D. J. (1994). Understanding the small business sector. London: Routledge.

35. Walker, E. (2003). Home-based businesses: Setting straight the urban myths. Small Enterprise Research, $11(2), 35-48$.

36. Walker, E., \& Brown, A. (2004). What Success Factors are Important to Small Business Owners? International Small Business Journal, 22(6), 577-594.

37. Walker, E., \& Webster, B. (2004). Gender issues in home-based businesses. Women in management review, 19(7/8), 404-412.

38. Walker, E., Weigall, F., \& Horgan, M. (2004, 26-29 Sept). Home-based businesses as a policy issue. Paper presented at the 17th Annual SEAANZ Conference - Entrepreneurship as the way of the Future, Brisbane.

39. Yellow Pages. (Ed.). (1995). A Special Report On Small Business Growth Aspirations and the Role of Exports: Yellow Pages. 


\section{NOTES}

